Diseases, Bethesda, Maryland, and the Fund for Research and Teaching, Department of Nutrition, Harvard School of Public Health, Boston, Massachusetts.

JoSEPF B. FASHAKIN D. M. Hegsted

Department of Nutrition,

Harvard School of Public Health,

Boston, Massachusetts 02115.

Received April 16; revised April 27, 1970.

${ }^{1}$ Schimke, R. T., J. Biol. Chem., 239, 3808 (1964).

2 Schimke, R. T., in Mammalian Protein Metabolism (edit. by Munro, II. N.) (Academic Press, in the press).

s Neuberger, A., and Richards, F. F., in Mammalian Protein Metabolism (edit. by Munro, H. N., and Allison, J. B.), 1 (Academic Press, 1964).

4 Waterlow, J. C., and Stephen, J. M. I., Clin. Sci., 35, 287 (1968).

${ }^{5}$ Gan, J. C., and Jeffay, H., Biochim. Biophys. Acta, 148, 448 (1967).

'Goldberg, A. L., J. Biol. Chem., 244, 3217 (1969).

$?$ Goldberg, A. L., J. Biol. Chem., 244, 3223 (1969).

8 Nutrition Rev., 28, 45 (1970).

\section{Changes in the Properties of Reconstituted Collagen brought about by Mechanical Treatment}

Gross has shown that the decreasing ability of a collagen gel to pass back into solution when the $p \mathrm{H}$ or the temperature is lowered represents an ageing effect in in vitro collagen gels ${ }^{1}$. These alterations in physical properties may be a result of the formation of covalent cross linkages between oxidized lysine residues in one tropocollagen molecule and free lysine $\varepsilon$-amino groups in adjacent ones. We have shown that similar changes in physical properties and alterations in the enzyme susceptibility of the precipitated collagen are caused by the application of cyclical mechanical stress to the collagen during tho period of precipitation.

Polymeric collagen was obtained from three year old bovine achilles tendon by exhaustive extraction with $5 \mathrm{M} \mathrm{NaCl}$ to remove all the soluble proteins ${ }^{3}$ and prolonged incubation with crudo $\alpha$-amylase. After dispersion in acetic acid and reprecipitation with $\mathrm{NaOH}$, a solution was prepared in $0.2 \mathrm{M}$ acetic acid containing $75 \mathrm{mg}$ protein $/ 100 \mathrm{ml}$., measured by the method of Lowry et al. ${ }^{4}$ using gelatine as standard. This material conformed to the standards of purity suggested by Grant and Jackson ${ }^{5}$ by having less than 1 mole of hexosamine and 6 moles of hexose per ninety-four residues of hydroxyproline. 'This solution was slowly neutralized by exposure to an atmosphere of moist ammonia at $20^{\circ} \mathrm{C}$ for $16 \mathrm{~h}$. The precipitated gel, consisting of fine fibrils up to $2 \mathrm{~mm}$ in length, was shaken with acetic acid to determine the reversibility of the "ageing" process. After shaking for $5 \mathrm{~h}$ with $5 \mathrm{ml}$. of $0 \cdot 2 \mathrm{M}$ acetic acid, $46 \cdot 6 \pm 8 \cdot 4$ per cent of the gel prepared from $0.2 \mathrm{ml}$. of the collagen solution redissolved. Other samples of precipitated collagen were subjected to cyclical alterations in mechanical stress. 'These were produced by a specially designed piece of apparatus in which the collagen is stretched by precipitation in a nylon mesh, the area of which is extended by 33.6 per cent every $8 \mathrm{~min}$ by a piston. Collagen $(0.2 \mathrm{ml}$. of $0.075 \mathrm{per}$ cent solution) was applied to the centre of the nylon; the piston was set in motion, and the vessel containing the piston and mesh was filled with a mixture of nitrogen and moist ammonia. The rate of passage of the ammonia was regulated so that precipitation of the collagen fibres, as indicated by the appearance of opacity in the liquid in the nylon mesh, appeared after $3 \mathrm{~h}$. A similar amount of collagen solution supported on an unstretched mesh was exposed to the same alkaline atmosphere in the body of the vessel at the same time.

Sixteen hours after the initial application of the collagen solution, disks of fabric $2.5 \mathrm{~cm}$ in diameter were cut from the stretched and unstretched samples. In one series of experiments the two separate pieces of fabric with their entrained collagen precipitates were shaken for $5 \mathrm{~h}$ in $5 \mathrm{ml}$. of $0.2 \mathrm{M}$ acetic acid. In the other series they were divided into two equal portions; one was incubated in $5 \mathrm{ml} .0 .2 \mathrm{M}$ sodium acetate buffer $(p \mathrm{H} 7 \cdot 8)$ containing $0.01 \mathrm{M}$ calcium chloride and $100 \mu \mathrm{g}$ of Clostridium collagenase, and the other was incubated in $5 \mathrm{ml}$. $0.15 \mathrm{M}$ borate buffer $(p \mathrm{H} 8 \cdot 4)$ containing $100 \mu \mathrm{g}$ pancreatic clastase ${ }^{6}$. Both preparations were incubated at $37^{\circ} \mathrm{C}$ for $3 \mathrm{~h}$ and, after filtration, the solubilized protein was measured with a biuret reagent?

In contrast to the unstretched sample, only $15 \cdot 0 \pm 2 \cdot 3$ per cent of the stretched precipitate redissolved in acctic acid, a difference which is significant at the $P=0.005$ level. A 34 per cent stretch decreased the collagenase susceptibility of the precipitated fibres (measured in arbitrary units) from 56 to 42 , whereas the clastase susceptibility increased from 8 to 17 , an increase of 112 per cent. This change in relative susceptibility is significant below the $P=0.01$ level. It therefore seems that mechanical stress has two effects on neutralized collagen fibre: the fibrous gel is rendered less extractable with acetic acid and the susceptibility to digestion by elastase is increased whilst that by collagenase is decreased.

Keech ${ }^{8}$ demonstrated (by electron microscopy) that the appearance of collagen gels changes considerably when it is stirred vigorously shortly after precipitation. Even the less drastic treatment used here may also affect the physical state of collagen. A reduction in solubility might indicate that an increasing number of cross links are formed. This could be attributed to an alignmont of the molecules that brings the reactive centres in adjacent peptide chains sufficiently close to one another for reaction to take place. On the other hand, the changes which are observed in the relative enzymic susceptibility seem to necessitate exactly the opposito situation, namely one of denaturation and disorientation: Fall et al. ${ }^{9}$ and Banga and $\mathrm{Balo}^{10}$ have demonstrated that denatured collagen is more susceptible to elastaso than native collagen. This contradiction can be rationalized, however, if one assumes that the stretching alters the spatial relationships of carboxyl and hydroxyl groups in the collagen molecule in a fashion that renders them capable of attracting and binding elastase, similar to that which occurs in elastin $1 x$.

Department of Medicine,

University of Leeds.

Received June 10; revised July 17.

${ }^{1}$ Gross, J., J. Exp. Med., 107, 247 (1958).

2 Bailey, A. J., Gerontologia, 15, 65 (1969).

${ }^{3}$ Steven, F., Ann. Rheum. Dis., 23, 300 (1964).

- Lowry, O. II., Rosebrough, N. J., Farr, A. I., and Randall, R. J., J. Biol. Chem., 193, 265 (1951).

5 Grant, M. F., and Jackson, 1)., Biochem. J., 108, 587 (1968).

${ }^{6}$ Hall, D. A., and Czerkawski, J. W., Biochem. J., 73, 356 (1959).

${ }^{2}$ Hall, D. A., and Gardiner, J. F., Biochem. J., 59, 465 (1955).

${ }^{8}$ Keech, M. K., Michigan State Med. J., 60, 321 (1961).

- Hall, 1. A., Tunbridge, R. E., and Wood, G. C., Nature, 172, 1099 (1953). 10 Banga, I., Nature, 172, 1099 (1953).

${ }^{11}$ Hall, .D. A., and Cyerkawski, J. W., in Collagen (edit. by Ramachandran, J.), 419 (Interscience, New York, 1961).

\section{Increased Recovery of Anaesthetized Hypothermic Rats induced by Intracarotid Infusion}

WE have shown previously that if rats were cooled to cardiac arrest without assisted ventilation, held thus for $30 \mathrm{~min}$, and rewarmed with artificial ventilation, only 9 per cent of them recovered ${ }^{1,2}$. 'This incidence could be increased to 45 per cent if their abdomens werc pumped 